\title{
VISCOELASTIC MODEL FOR THE RIGID BODY VIBRATIONS OF A VIADUCT DEPENDING ON THE SUPPORT DEVICES' RHEOLOGICAL MODEL
}

Polidor Bratu, Prof., PhD, Dipl. Eng., Dr. h. c., ICECON S.A., e-mail: icecon@ icecon.ro Ovidiu Vasile, Lect., PhD, Dipl. Eng., ICECON S.A., e-mail: ovidiu.vasile@ @icecon.ro

\section{Rezumat}

Lucrarea abordează comportarea unui model de solid-rigid cu anumite simetrii structurale. Aceste simetrii permit simplificarea calculelor (ecuaţii de mişcare) şi, deci, a modelelor matematice. Dacă solidul rigid este conectat la structură prin patru legături elastice, modelul rămâne încă simplu şi uşor de rezolvat, vibraţiile putând fi decuplate în patru subsisteme de mişcare.

În final, se prezintă un studiu de caz pentru analiza modală a unui viaduct, modelat precum un corp solid-rigid, rezemat elastic, de pe autostrada Transilvania (km 29+602.75 m).

Cuvinte cheie: viaduct, aparate de reazem, vibraţii.

\section{Abstract}

The paper addresses the behavior of a rigid solid with various structural symmetries. These symmetries allow the simplification of computations (equations of motion) and, thus, also of the mathematical models. If the rigid solid is connected to the structure through four elastic links, the model still remains simple and easy to solve by decomposing the vibrations into four subsystems of motion: side slipping and rolling, forward motion and pitching, lifting motion, gyration.

In the end, a case study is presented for the modal analysis of a viaduct, modeled as a rigid solid, elastically supported, on the Transilvania highway at $\mathrm{km} 29+602.75 \mathrm{~m}$.

Keywords: viaduct, support devices, vibrations.

\section{MATHEMATICAL MODELING OF THE RIGID SOLID WITH ELASTIC BEARINGS}

The mathematical modeling uses the physical model of the rigid solid with six degrees of freedom (6DOF) with a finite number of viscous-elastic bearings. Dimensional and inertial characteristics of the rigid solid and rheological characteristics of the bearings (stiffness and damping) can be 
experimentally determined by direct measurements and by static and/or dynamic testing. According to (7), the differential equations of the movements of the rigid solid with viscous-elastic bearings are coupled by stiffness and damping coefficients. The system of the equations can be write as follows:

$$
\underline{A} \underline{\underline{q}}+\underline{B} \underline{\underline{q}}+\underline{C} \underline{\underline{q}}=\underline{\underline{f}},
$$

where $\underline{A}$ is the inertia matrix; $\underline{B}$ is the viscous damping matrix (damping coefficients); $\underline{C}$ is the elasticity matrix (stiffness coefficients); $\underline{\underline{q}} / \underline{\underline{q}} / \underline{\underline{q}}$ are generalized displacements / velocities / accelerations vector and $\underline{\underline{f}}$ is the generalized forces vector. becomes:

If the damping coefficients are small, the differential equations system

$$
\underline{A} \underline{\underline{a}}+\underline{\underline{C}} \underline{\underline{q}}=\underline{\underline{f}}
$$

Considering the rigid solid no perturbated, the system of differential equations becomes:

$$
\underline{A} \underline{\underline{q}}+\underline{C} \underline{\underline{q}}=\underline{\underline{O}},
$$

where $\underline{\underline{O}}$ is the null vector (where all coefficients are zero).

If the Cartesian coordinates axis system is central and principal, the quadratic $6 \times 6$ inertia matrix becomes diagonal

$$
\underline{A}=D I A G\left\lfloor m, m, m, J_{x}, J_{y}, J_{z}\right\rfloor,
$$

where $m$ is the rigid solid mass and $J_{x}, J_{y}, J_{z}$ are the principal inertia moments.

\section{THE RIGID SOLID WITH STRUCTURAL SYMMETRIES. MODAL ANALYSIS}

Considering that the rigid solid has a vertical axis of symmetry (mass distribution, geometrical configuration, bearings disposal) and the coordinate system is central and principal, the inertia matrix is diagonal.

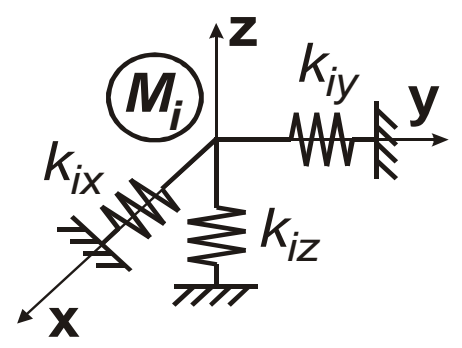

Figure 1. Elastic triorthogonal bearing 
If the elastic bearing system of the rigid solid is composed from $n$ supports with triorthogonal stiffness $\left(k_{i x}, k_{i y}, k_{i z}\right)$ like in figure 1 , with the position done by the coordinates $M_{i}\left(x_{i}, y_{i}, z_{i}\right) i=\overline{1, n}$, the elasticity matrix becomes:

$$
\underline{C}=\left[\begin{array}{cccccc}
\sum k_{i x} & 0 & 0 & 0 & \sum k_{i x} z_{i} & 0 \\
0 & \sum k_{i y} & 0 & -\sum k_{i y} z_{i} & 0 & 0 \\
0 & 0 & \sum k_{i z} & 0 & 0 & 0 \\
0 & -\sum k_{i y} z_{i} & 0 & \sum\left(k_{i y} z_{i}^{2}+k_{i z} y_{i}^{2}\right) & 0 & 0 \\
\sum k_{i x} z_{i} & 0 & 0 & 0 & \sum\left(k_{i z} x_{i}^{2}+k_{i x} z_{i}^{2}\right) & 0 \\
0 & 0 & 0 & 0 & 0 & \sum\left(k_{i x} y_{i}^{2}+k_{i y} x_{i}^{2}\right)
\end{array}\right]
$$

As the inertia matrix is diagonal, the coefficients outside the main diagonal of the elasticity matrix $\underline{C}$ are the coupling terms of the equations of the system (3). Because there are only four non-zero stiffness coefficients ( $c_{15} \equiv c_{51}$ and $\left.c_{24}=c_{42}\right)$, the free movements of the rigid solid are decoupled into four subsystems with coupled vibrations. The subsystems with coupled motion equations are as follows:

a) subsystem $\left(X, \varphi_{y}\right)$ - side slip movement coupled with rolling movement

$\left\{\begin{array}{c}m \ddot{X}+X \sum k_{i x}+\varphi_{y} \sum k_{i x} z_{i}=0 \\ J_{y} \ddot{\varphi}_{y}+X \sum k_{i x} z_{i}+\varphi_{y} \sum\left(k_{i z} x_{i}^{2}+k_{i x} z_{i}^{2}\right)=0\end{array}\right.$

b) subsystem $\left(Y, \varphi_{x}\right)$ - forward-back movement coupled with pitch movement

$\left\{\begin{array}{c}m \ddot{Y}+Y \sum k_{i y}-\varphi_{x} \sum k_{i y} z_{i}=0 \\ J_{x} \ddot{\varphi}_{x}-Y \sum k_{i y} z_{i}+\varphi_{x} \sum\left(k_{i y} z_{i}^{2}+k_{i z} y_{i}^{2}\right)=0\end{array}\right.$

c) subsystem $(Z)$ - up-down movement

$m \ddot{Z}+Z \sum k_{i z}=0$

d) subsystem $\left(\varphi_{z}\right)$ - turning movement (gyration)

$J_{z} \ddot{\varphi}_{z}+\varphi_{z} \sum\left(k_{i x} y_{i}^{2}+k_{i y} x_{i}^{2}\right)=0$

In order to determinate the natural frequencies and the eigenvalues we use the next notations:

- for the pulsations of the no coupled movements of translation 


$$
p_{X}=\sqrt{\frac{\sum k_{i x}}{m}} \quad p_{Y}=\sqrt{\frac{\sum k_{i y}}{m}} p_{Z}=\sqrt{\frac{\sum k_{i z}}{m}}
$$

- for the pulsations of the no coupled movements of rotation

$$
\begin{aligned}
& p_{\varphi_{x}}=\sqrt{\frac{\sum\left(k_{i y} z_{i}^{2}+k_{i z} y_{i}^{2}\right)}{J_{x}}} \quad p_{\varphi_{y}}=\sqrt{\frac{\sum\left(k_{i z} x_{i}^{2}+k_{i x} z_{i}^{2}\right)}{J_{y}}} \\
& p_{\varphi_{z}}=\sqrt{\frac{\sum\left(k_{i x} y_{i}^{2}+k_{i y} x_{i}^{2}\right)}{J_{z}}}
\end{aligned}
$$

- the dynamic coupling terms for the $\left(X, \varphi_{y}\right)$ and $\left(Y, \varphi_{x}\right)$ subsystems

$$
\left\{\begin{array} { l } 
{ \alpha _ { 1 } = \frac { 1 } { m } \sum k _ { i x } z _ { i } } \\
{ \alpha _ { 2 } = \frac { 1 } { J _ { y } } \sum k _ { i x } z _ { i } }
\end{array} \quad \left\{\begin{array}{l}
\beta_{1}=-\frac{1}{m} \sum k_{i y} z_{i} \\
\beta_{2}=-\frac{1}{J_{x}} \sum k_{i y} z_{i}
\end{array}\right.\right.
$$

Considering the relations (10) and (11), the natural pulsations and the eigenvalues of the decoupled subsystems can be determinate with the next calculus formula:

a) for the subsystem $\left(X, \varphi_{y}\right)$

$$
\begin{aligned}
& p_{1,2}=\sqrt{\frac{1}{2}\left[p_{X}^{2}+p_{\varphi_{y}}^{2} \mp \sqrt{\left.\left(p_{X}^{2}-p_{\varphi_{y}}^{2}\right)^{2}+4 \alpha_{1} \alpha_{2}\right]}\right.} \\
& \mu_{1,2}=-\frac{1}{2 \alpha_{1}}\left[p_{X}^{2}+p_{\varphi_{y}}^{2} \pm \sqrt{\left(p_{X}^{2}-p_{\varphi_{y}}^{2}\right)^{2}+4 \alpha_{1} \alpha_{2}}\right]
\end{aligned}
$$

b) for the subsystem $\left(Y, \varphi_{x}\right)$

$$
\begin{aligned}
p_{3,4} & =\sqrt{\frac{1}{2}\left[p_{Y}^{2}+p_{\varphi_{x}}^{2} \mp \sqrt{\left(p_{Y}^{2}-p_{\varphi_{x}}^{2}\right)^{2}+4 \beta_{l} \beta_{2}}\right]} \\
\mu_{3,4} & =-\frac{1}{2 \beta_{l}}\left[p_{Y}^{2}+p_{\varphi_{x}}^{2} \pm \sqrt{\left(p_{Y}^{2}-p_{\varphi_{x}}^{2}\right)^{2}+4 \beta_{I} \beta_{2}}\right]
\end{aligned}
$$

\section{MODAL ANALYSIS OF A BRIDGE MADE FROM REINFORCED CONCRETE}

Figure 2 shows elevation and the plan view for a bridge made from twenty reinforced concrete beams jointed through a $300 \mathrm{~mm}$ thickness 
ROMANIAN JOURNAL

OF TRANSPORT INFRASTRUCTURE

reinforced concrete plate. Each beam is beared on the piers and on the abutments of the bridge through four identically viscous-elastic supports made from neoprene; there a total number of eighty neoprene bearings for the entire bridge.

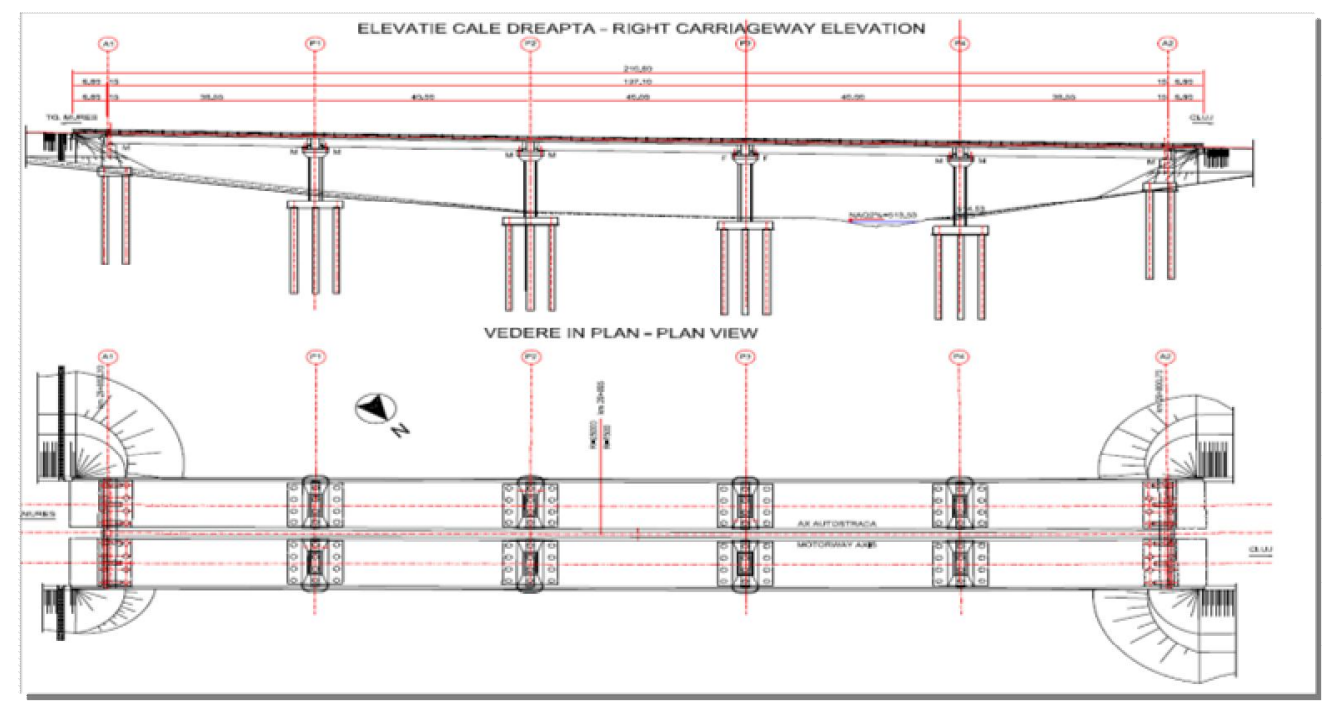

Figure 2. Elevation and plan view of the Viaduct Romanian highway A3 - KM 29+602,75↔KM 29+801,25

The simplified model of the bridge is shown in the figure 3 . In order to calculate the natural pulsations and frequencies and the eigenvalues of the bridge modeled as in the figure 2, the main characteristics are the next:

- Dimensions (as in detailed engineering drawings and/or measured):

-for "U" beams: $37100 \times 1700 / 3280 \times 2200$ lenght $\times$ width $\times$ height $[\mathrm{mm}]$

- for the bridge: $200000 \times 13300 \times 2500$ lenght $\times$ width $\times$ height $[\mathrm{mm}]$

- Stiffness of the neoprene bearings (experimental measurements):

$$
\begin{array}{ll}
k_{i x} \equiv k_{x}=3,15 \times 10^{6} \mathrm{~N} / \mathrm{m} & i=\overline{1,80} \\
k_{i y} \equiv k_{y}=3,15 \times 10^{6} \mathrm{~N} / \mathrm{m} & i=\overline{1,80} \\
k_{i z} \equiv k_{z}=650 \times 10^{6} \mathrm{~N} / \mathrm{m} & i=\overline{1,80}
\end{array}
$$

- Masses and inertia according to table 1 (calculated): 
ROMANIAN JOURNAL

OF TRANSPORT INFRASTRUCTURE

Table 1. Inertial characteristics (central and principal axis system)

\begin{tabular}{|c|c|c|c|c|}
\hline \multicolumn{2}{|c|}{ Denomination } & Unit & $\begin{array}{c}\text { Arch of the viaduct (4 } \\
\text { beams) }\end{array}$ & Viaduct ( 20 beams) \\
\hline \multicolumn{2}{|c|}{ Mass $m$} & $\mathrm{~kg}$ & 992,000 & $4,960,000$ \\
\hline \multicolumn{2}{|c|}{$\begin{array}{l}\text { Products of } \\
\text { inertia }\end{array}$} & $\mathrm{Kg} \cdot \mathrm{m}^{2}$ & \multicolumn{2}{|c|}{$J_{x y}=J_{y z}=J_{z x}=0$} \\
\hline \multirow{3}{*}{$\begin{array}{c}\text { Moments } \\
\text { of } \\
\text { inertia }\end{array}$} & $J_{x}$ & $\mathrm{Kg} \cdot \mathrm{m}^{2}$ & $120.533 \times 10^{6}$ & $16.025 \times 10^{9}$ \\
\hline & $J_{y}$ & $\mathrm{Kg} \cdot \mathrm{m}^{2}$ & $15.133 \times 10^{6}$ & $73.270 \times 10^{6}$ \\
\hline & $J_{z}$ & $\mathrm{Kg} \cdot \mathrm{m}^{2}$ & $134.091 \times 10^{6}$ & $16.092 \times 10^{9}$ \\
\hline
\end{tabular}

- Position of the mass center $\mathrm{C}$ against the neoprene bearings (calculated): $h=1454,4 \mathrm{~mm}$

- Positions of the neoprene bearings on the viaduct (related to the centered coordinate system Cxyz) as in detailed engineering drawings - see table 2 .

Table 2. Positions of the neoprene bearings

\section{Bearing and coordinates [m]}

\begin{tabular}{|c|c|c|c|c|c|c|c|c|c|c|c|c|c|c|}
\hline i & $\mathbf{y}_{\mathbf{i}}$ & $\mathbf{z}_{\mathbf{i}}$ & $\mathbf{i}$ & $\mathbf{x}_{\mathbf{i}}$ & $\mathbf{y}_{\mathbf{i}}$ & $\mathbf{z}_{\mathbf{i}}$ & $\mathbf{i}$ & $\mathbf{x}_{\mathbf{i}}$ & $\mathbf{y}_{\mathbf{i}}$ & $\mathbf{z}_{\mathbf{i}}$ & i & $\mathbf{x}_{\mathbf{i}}$ & $\mathbf{y}_{\mathbf{i}}$ & $\mathbf{z}_{\mathbf{i}}$ \\
\hline 1 & $-5,5-98,05$ & $-1,45$ & 21 & 1,1 & 8,05 & $-1,45$ & 41 & $-5,5$ & 18,05 & $-1,45$ & 61 & 1,1 & 8,05 & $-1,45$ \\
\hline 2 & $-4,4-98,0$ & $-1,45$ & 22 & 2,2 & -58 & $-1,45$ & 42 & $-4,4$ & 18,05 & $-1,45$ & 62 & 2,2 & 8,05 & $-1,45$ \\
\hline 3 & $-2,2-98,05$ & $-1,45$ & 23 & 4,4 & $-58,05$ & \begin{tabular}{|l|}
$-1,45$ \\
\end{tabular} & 43 & $-2,2$ & 18,05 & $-1,45$ & 63 & 4,4 & 58,05 & $-1,45$ \\
\hline 4 & $-1,1-98,05$ & $-1,45$ & 24 & 5,5 & -58, & $-1,45$ & 44 & $-1,1$ & 18,05 & $-1,45$ & 64 & 5,5 &, 05 & $-1,45$ \\
\hline 5 & $1,1-98,05$ & $-1,45$ & 25 & $-5,5$ & $-21,95$ & $-1,45$ & 45 & 1,1 & 18,05 & $-1,45$ & 65 & $-5,5$ & 61,95 & $-1,45$ \\
\hline 6 & $2,2-98,05$ & $-1,45$ & 26 & $-4,4$ & $-21,95$ & $-1,45$ & 46 & 2,2 & 18,05 & $-1,45$ & 66 & $-4,4$ & 95 & $-1,45$ \\
\hline 7 & $\begin{array}{l}4,4-98 \\
\end{array}$ & $-1,45$ & 27 & $-2,2$ & -21 & $-1,45$ & 47 & 4,4 & 18,05 & $-1,45$ & 67 & $-2,2$ & 61,95 & $-1,45$ \\
\hline 8 & \begin{tabular}{l|l|}
$5,5-98,05$ \\
\end{tabular} & $-1,45$ & 28 & $-1,1$ & $-21,95$ & $-1,45$ & 48 & 5,5 & 18,05 & $-1,45$ & 68 & $-1,1$ & 61,95 & $-1,45$ \\
\hline 9 & $-5,5-61,95$ & $-1,45$ & 29 & 1,1 & -21 & $-1,45$ & 49 & $-5,5$ & 21,95 & $-1,45$ & 69 & 1,1 & 95 & $-1,45$ \\
\hline 10 & $-4,4-61,95$ & $-1,45$ & 30 & 2,2 & $-21,95$ & $-1,45$ & 50 & $-4,4$ & 21,95 & $-1,45$ & 70 & 2,2 & 61,95 & $-1,45$ \\
\hline 11 & $-2,2-61,95$ & $-1,45$ & 31 & 4,4 & -21, & $-1,45$ & 51 & $-2,2$ & 21,95 & $-1,45$ & 71 & 4, & 95 & $-1,45$ \\
\hline 12 & $-1,1-61,95$ & $-1,45$ & 32 & 5,5 & $-21,95$ & $-1,45$ & 52 & $-1,1$ & 21,95 & $-1,45$ & 72 & 5,5 & 61,95 & $-1,45$ \\
\hline 13 & $1,1-61,95$ & $-1,45$ & 33 & $-5,5$ & $-18,05$ & $-1,45$ & 53 & 1,1 & 21,95 & $-1,45$ & 73 & $-5,5$ & 98,05 & $-1,45$ \\
\hline 14 & $2,2-61,95$ & $-1,45$ & 34 & $-4,4$ & -18, & $-1,45$ & 54 & 2,2 & 21,95 & $-1,45$ & 74 & $-4,4$ & 98,05 & $-1,45$ \\
\hline 15 & $4,4-61,95$ & $-1,45$ & 35 & $-2,2$ & $-18,05$ & $-1,45$ & 55 & 4,4 & 21,95 & $-1,45$ & 75 & $-2,2$ & 98,05 & $-1,45$ \\
\hline 16 & $5,5-61,95$ & $-1,45$ & 36 & $-1,1$ & $-18,05$ & $-1,45$ & 56 & 5,5 & 21,95 & $-1,45$ & 76 & $-1,1$ & 98,05 & $-1,45$ \\
\hline 17 & $-5,5-58,05$ & $-1,45$ & 37 & 1,1 & $-18,05$ & $-1,45$ & 57 & $-5,5$ & 58,05 & $-1,45$ & 77 & 1,1 & 98,05 & $-1,45$ \\
\hline 18 & $-4,4-58,05$ & $-1,45$ & 38 & 2,2 & $-18,05$ & $-1,45$ & 58 & $-4,4$ & 58,05 & $-1,45$ & 78 & 2,2 & 98,05 & $-1,45$ \\
\hline 19 & $-2,2-58,05$ & $-1,45$ & 39 & 4,4 & $-18,05$ & $-1,45$ & 59 & $-2,2$ & 58,05 & $-1,45$ & 79 & 4,4 & 98,05 & $-1,45$ \\
\hline 20 & $-1,1-58,05$ & $-1,45$ & 40 & 5,5 & 18,05 & $-1,45$ & 60 & $-1,1$ & 58,05 & $-1,45$ & 80 & 5,5 & 98,05 & $-1,45$ \\
\hline
\end{tabular}


Table 3. Natural pulsations and frequencies (on the six degrees of dynamic freedom)

\begin{tabular}{|c|c|c|c|c|c|c|c|}
\hline $\begin{array}{c}\text { Arch of the viaduct } \\
(4 \text { beams })\end{array}$ & $p[\mathrm{rad} / \mathrm{s}]$ & 7.13 & 7.13 & 102.39 & 167.67 & 97.83 & 11.30 \\
\cline { 2 - 8 } & $f[\mathrm{~Hz}]$ & 1.13 & 1.13 & 16.30 & 26.69 & 15.60 & 1.80 \\
\hline $\begin{array}{c}\text { Viaduct } \\
(20 \text { beams })\end{array}$ & $p[\mathrm{rad} / \mathrm{s}]$ & 7.13 & 7.13 & 102.39 & 105.49 & 97.83 & 7.34 \\
\cline { 2 - 8 } & $f[\mathrm{~Hz}]$ & 1.13 & 1.13 & 16.30 & 16.79 & 15.60 & 1.17 \\
\hline
\end{tabular}

Using the relations (10), the natural pulsations $p$ and the natural frequencies $f$ of the uncoupled vibrations for the six degrees of dynamic freedom are shown in the table 3.

The figures from table 4 show the values of the natural pulsations and frequencies and of the eigenvalues for the decoupled subsystems (with coupled movements) for a bridge section (arche) composed from four „U” beams as in figure 4 and figure 5 .

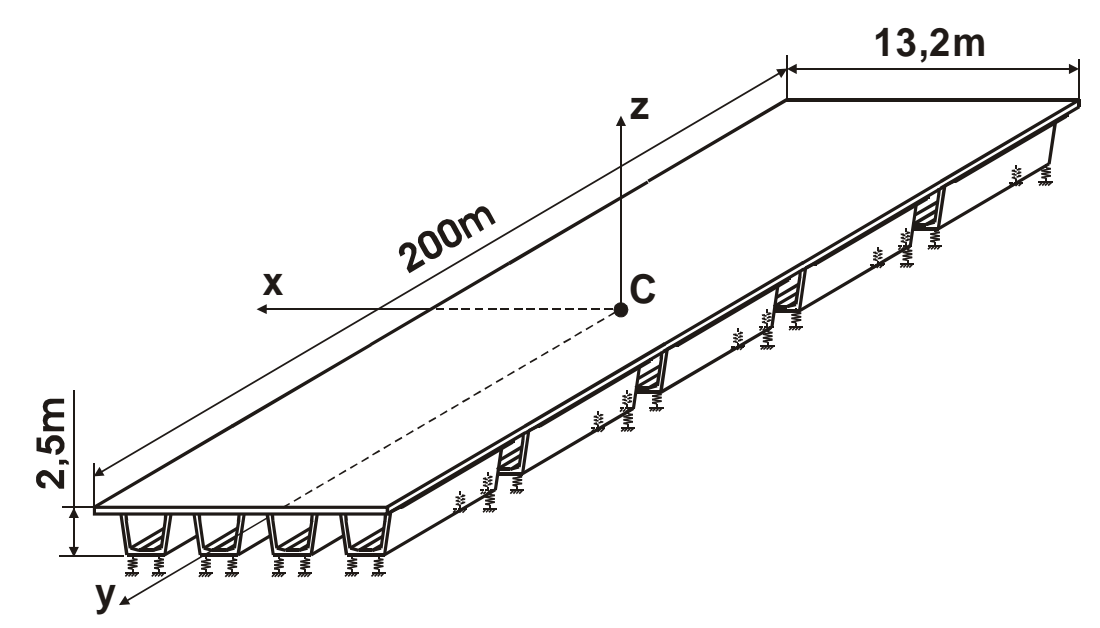

Figure 3. The model of the bridge beared on eighty neoprene supports

As it can see, there are the same values for pulsations and frequencies like in table 3. That means, the movements inside the subsystems $\left(X, \varphi_{y}\right)$ and $\left(Y, \varphi_{x}\right)$ are very weak coupled, almost uncoupled. 
ROMANIAN JOURNAL

OF TRANSPORT INFRASTRUCTURE

Polidor Bratu, Ovidiu Vasile

Viscoelastic model for the rigid body vibrations of a viaduct depending on the support devices rheological model

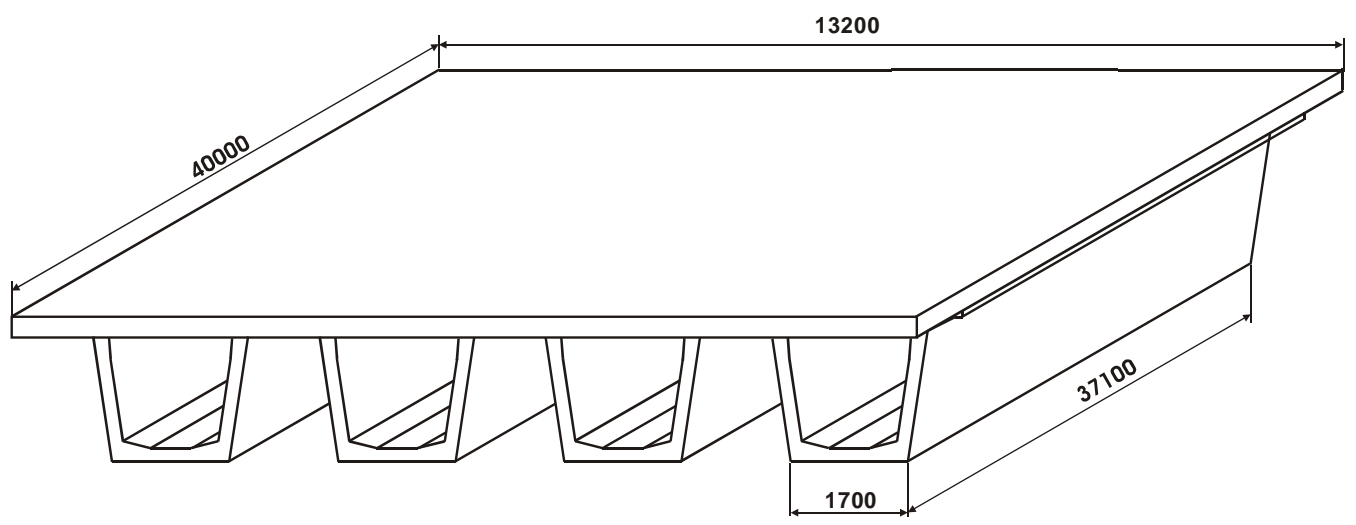

Figure 4. The model of an arch of the viaduct

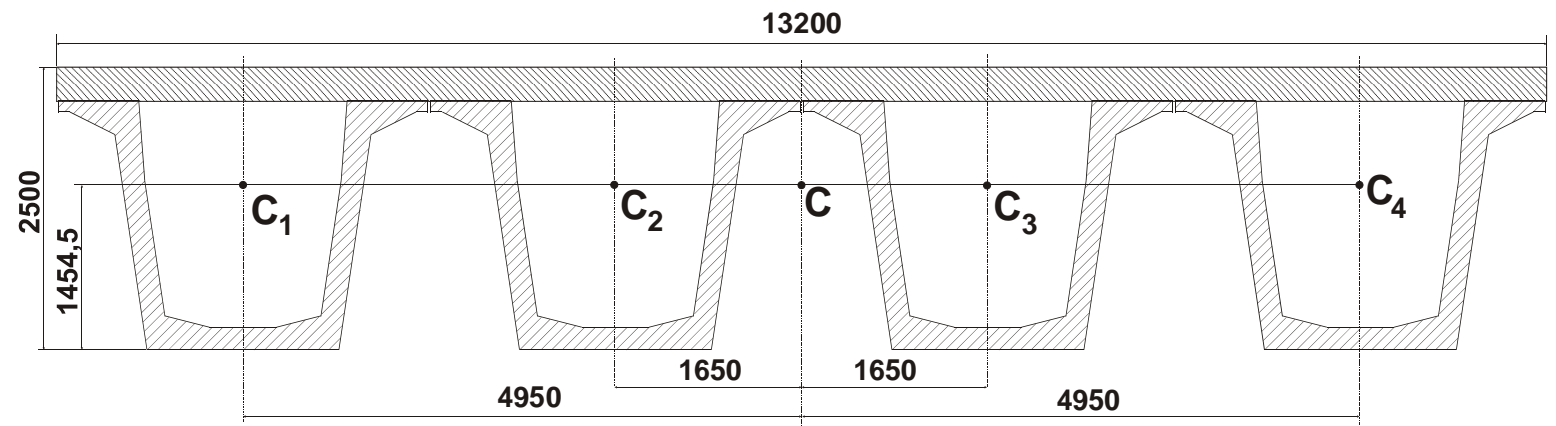

Figure 5. The model of an arch of the viaduct (transversal section)

Table 4. Modal analyze for an arch (section) of the viaduct (decoupled subsystems)

\begin{tabular}{|c|c|c|c|}
\hline Subsystem & Pulsations & Frequencies & Eigenvalues \\
\hline \multirow{2}{*}{$\left(X, \varphi_{y}\right)$} & $p_{1}=7.13 \mathrm{rad} / \mathrm{s}$ & $f_{1}=1.13 \mathrm{~Hz}$ & $\mu_{1}=0.000509 \mathrm{rad} / \mathrm{m}$ \\
\cline { 2 - 4 } & $p_{2}=97.83 \mathrm{rad} / \mathrm{s}$ & $f_{2}=15.60 \mathrm{~Hz}$ & $\mu_{2}=-128.824 \mathrm{rad} / \mathrm{m}$ \\
\hline \multirow{2}{*}{$\left(Y, \varphi_{x}\right)$} & $p_{3}=7.13 \mathrm{rad} / \mathrm{s}$ & $f_{3}=1.13 \mathrm{~Hz}$ & $\mu_{3}=-0.000002 \mathrm{rad} / \mathrm{m}$ \\
\cline { 2 - 4 } & $p_{4}=167.67 \mathrm{rad} / \mathrm{s}$ & $f_{4}=26.69 \mathrm{~Hz}$ & $\mu_{4}=379.750 \mathrm{rad} / \mathrm{m}$ \\
\hline$(Z)$ & $p_{5}=p_{Z}=102.39 \mathrm{rad} / \mathrm{s}$ & $f_{5}=f_{Z}=16.30 \mathrm{~Hz}$ & - \\
\hline$\left(\varphi_{z}\right)$ & $p_{6}=p_{\varphi_{z}}=11.30 \mathrm{rad} / \mathrm{s}$ & $f_{6}=f_{\varphi_{z}}=1.80 \mathrm{~Hz}$ & - \\
\hline
\end{tabular}


ROMANIAN JOURNAL

OF TRANSPORT INFRASTRUCTURE

Polidor Bratu, Ovidiu Vasile

Viscoelastic model for the rigid body vibrations of a viaduct depending on the support devices rheological model

Table 5. Modal analyze for the viaduct (decoupled subsystems)

\begin{tabular}{|c|c|c|c|}
\hline Subsystem & Pulsations & Frequencies & Eigenvalues \\
\hline \multirow{2}{*}{$\left(X, \varphi_{y}\right)$} & $p_{1}=7.13 \mathrm{rad} / \mathrm{s}$ & $f_{1}=1.13 \mathrm{~Hz}$ & $\mu_{1}=0.000509 \mathrm{rad} / \mathrm{m}$ \\
\cline { 2 - 4 } & $p_{2}=97.83 \mathrm{rad} / \mathrm{s}$ & $f_{2}=15.57 \mathrm{~Hz}$ & $\mu_{2}=-128.824 \mathrm{rad} / \mathrm{m}$ \\
\hline \multirow{2}{*}{$\left(Y, \varphi_{x}\right)$} & $p_{3}=7.13 \mathrm{rad} / \mathrm{s}$ & $f_{3}=1.13 \mathrm{~Hz}$ & $\mu_{3}=-0.000002 \mathrm{rad} / \mathrm{m}$ \\
\cline { 2 - 4 } & $p_{4}=105.49 \mathrm{rad} / \mathrm{s}$ & $f_{4}=16.79 \mathrm{~Hz}$ & $\mu_{4}=149.916 \mathrm{rad} / \mathrm{m}$ \\
\hline$(Z)$ & $p_{5}=p_{Z}=102.39 \mathrm{rad} / \mathrm{s}$ & $f_{5}=f_{Z}=16.30 \mathrm{~Hz}$ & - \\
\hline$\left(\varphi_{z}\right)$ & $p_{6}=p_{\varphi_{z}}=7.34 \mathrm{rad} / \mathrm{s}$ & $f_{6}=f_{\varphi_{z}}=1.17 \mathrm{~Hz}$ & - \\
\hline
\end{tabular}

The figures from table 5 show the values of the natural pulsations and frequencies and of the eigenvalues for the decoupled subsystems (with coupled movements) for the entire bridge composed from five sections (arches) considered being identical as in figure 3 .

As for the arches, the movements inside the subsystems with coupled movements $\left(X, \varphi_{y}\right)$ and $\left(Y, \varphi_{x}\right)$ of the viaduct are very weak coupled, almost uncoupled.

\section{CONCLUSIONS}

a) modeling a rigid solid with elastic or viscous-elastic bearings and symmetries (structural, inertial, bearings) lead to linear mathematical models more simple, with differential equations decoupled into subsystems easier to solve; in this case, we can highlight the influences of different kinds of characteristics (dimensions, masses, inertia, stiffness) on the dynamic parameters of the rigid solid (natural pulsations/frequencies, eigenvalues);

b) if the physical model of the rigid solid permits to chose a Cartesian coordinate system which is central and principal, then the differential equations of motion are coupled only by the coefficients outside of principal diagonal of elasticity matrix (elastic coupling of movements), eventually by the dissipation coefficients from the viscous damping matrix if they are significant;

c) comparing the values of the pulsations/frequencies from the tables 3,4 and 5 , we can say that the movements inside the subsystems are almost uncoupled on the "directions" $\left(X, Y, Z, \varphi_{x}, \varphi_{y}, \varphi_{z}\right)$; also the values very small or very big of the eigenvalues can explain the quasidecoupling of the movements inside of the subsystems;

d) analyzing the values from table 4 (for the arches), we can find a group of three natural frequencies in the domain $1.1 \div 1.2 \mathrm{~Hz}$, another one in the domain 
$15.6 \div 16.3 \mathrm{~Hz}$ and the 6-th frequency being much more bigger $(26.69 \mathrm{~Hz})$; this grouping of frequencies and the big differences between the values of domains' limits can be explained by the significant differences between the bearings stiffness on vertical axis $\mathrm{Cz}$ (compression effort) and on horizontal plane $\mathrm{xCy}$ (shear efforts);

e) analyzing the values from table 5 (for the entire bridge), we can find a group of three natural frequencies in the domain $1.1 \div 1.2 \mathrm{~Hz}$ and another three in the domain $15.6 \div 16.8 \mathrm{~Hz}$; in this case of simulation, the pitch movement $\left(\varphi_{x}\right)$ of the viaduct, which is almost decoupled from the forward-back movement $(Y)$, has a natural frequency more smaller than the pitch movement of a single arch because of a bigger value of the moment of inertia $J_{x}$ mainly.

\section{REFERENCES}

[1] P. BRATU: “Vibraţiile sistemelor elastice”, Editura Tehnică, Bucureşti, 2000.

[2]. P.BRATU: “Izolarea şi amortizarea vibraţiilor la utilajele de construcţii”, Redacţia publicaţiilor pentru construcţii, Bucureşti, 1982.

[3]. P. BRATU: “Sisteme elastice de rezemare pentru maşini şi utilaje”, Editura Tehnică, Bucureşti, 1990.

[4]. P.BRATU, N. DRAGAN : "L'analyse des mouvements désaccouplés appliquée au modèle de solide rigide aux liaisons élastiques", Analele Universităţii "Dunărea de Jos” din Galaţi, Fascicula XIV, 1997.

[5]. GH. BUZDUGAN, L. FETCU, M. RADEŞ: “Vibraţii mecanice”, Ed. Didactică şi Pedagogică, Bucureşti, 1982.

[6]. GH. BUZDUGAN: “Izolarea antivibratorie ”, Ed. Academiei Române, Bucureşti, 1993.

[7]. N. DRAGAN : "Contribuţii la analiza şi optimizarea procesului de transport prin vibraţii - teză de doctorat”, Universitatea "Dunărea de Jos", Galaţi, 2001.

[8]. C.M. HARRIS, C.E .CREDE: “Şocuri şi vibraţii” vol. I-III, Ed. Tehnică, Bucureşti, 1967-1969

[9]. D. INMAN: "Vibration with Control”, John Wiley and Sons Ltd., New Jersey, 2006.

[10]. S. RAO: “Mechanical Vibrations” Fourth Edition, Pearson Education Inc., New Jersey, 2004.

[11]. M. RĂDOI, E. DECIU: “Mecanica”, Editura Didactică şi Pedagogică, Bucureşti, 1977. 